\title{
EDWIN WIERINGA AND THE EXOTICISM OF THE MINDS OF INDONESIAN MUSLIMS
}

\author{
Media Zainul Bahri ${ }^{1}$ \\ UIN Syarif Hidayatullah Jakarta \\ zainul.bahri@uinjkt.ac.id
}

\begin{abstract}
This article elaborates in-depth the views of Edwin Wieringa on Indonesian Islam. Wieringa is Professor of Indonesian philology with special reference to Islamic cultures at the University of Cologne, Germany. In addition to philology, Wieringa also concerns himself with the Indonesian contemporary Islamic issues. According to Wieringa, various aspects of the minds of Indonesian Muslims in the past and present are always exotic, in the sense of "unique" and "attractive", and therefore motivates him to examine a lot of things about Indonesian Islam. For Wieringa, Indonesian Muslim cultural exoticism also shows a high civilization that must be appreciated by the Indonesian Muslims themselves. Dozens articles of Wieringa which explore the culture of Islam in this country shows that he has a remarkable contribution to the development of Indonesian Islamic and cultural studies.
\end{abstract}

Keywords: Edwin Wieringa, Exoticism, Culture, Mind, Indonesia Islam

\section{INTRODUCTION}

This article elaborates the views Edwin Wieringa that shed light on Islam and Indonesianism which he poured through articles in international publications. Edwin Wieringa, a professor of Indonesian philology with special reference to Islamic cultures at the university Köln Germany, is a senior researcher of ancient Islamic Javanese manuscripts and the phenomenon of contemporary Indonesian Islam. Engaging in the studies of Southeast Asia, particularly Indonesia, from the beginning to college at Leiden University in the Netherlands, to pursue a Ph.D in the field of Language and Culture of Indonesia, has made Wieringa's views on Indonesian Islam clear and

${ }^{1}$ I would like to thank Professor Edwin Wieringa for letting me interview him on many occasions in Köln-Germany and Leiden-Netherlands for the purposes of this article. I would also like to thank him for inviting me to do posdoctoral research at the Institute of Indonesian Islam (Institute he headed) for four semesters (March 2012-December 2013) on the sponsorship of the Alexander von Humboldt Stiftung, Germany. 
authentic, and in some respects quite surprising. Pak Edwin, he was popularly klnown among colleagues in Indonesia, is the last generation trained in Javanese literature program in the 1980s, a time when literature and culture at the University of Leiden Java was still a "prima donna". After he graduated in 1994, the program was closed until today. However, the interesting part of Wieringa is that he has also conducted a lot of research and publications on contemporary phenomena of popular Islam in Indonesia and Malaysia.

\section{MORE ABOUT EDWIN WIERINGA}

In the study of philology of Indonesian Islam, Edwin Wieringa is a very familiar figure. Every year, at least twice Wieringa comes to the event of the congress of Manassa (Indonesian Manuscript Society), and another event at the Ministry of Religious Affairs or becomes a guest speaker at academic events held by UIN Jakarta, UI and UGM. In 2013, he also served as a Visiting Professor at the Graduate School of UIN Jakarta for half a semester. Edwin Paul Wieringa was born in Groningen, Holland, August 31, 1964, to native Dutch parents. His father was an accountant at a beverage factory in Groningen. When Wieringa was nine years old, he and his family moved to Roosendaal, Southern Holland, an area close to the Belgian border. The family had to move because the factory where his father worked in was closed in Groningen and moved to Roosendaal. Wieringa lived in Roosendaal until graduating from high school in 1982, and immediately continued his studies at Leiden University, Department of History. ${ }^{2}$

Wieringa in fat "fell in love" with the world of Asia, including Indonesia, since he was a teenager. He liked anything about Asia. He often read novels and books on Asia. During school visits to the museums, it was always interesting for him to see the world of Asia and Indonesia. According to Wieringa, in his school years, he did not know anything about Asia, but he already had the passion and imagination of Asia as a "beautiful and exotic" place, very different from Western culture. His interest might have something to do with his family background which has a conncetion with Indonesia. His father, Jan Wieringa, was born in Batavia in 1932 (in the Dutch colonial period). At that time, his grandfather, Menne Wieringa, had a career as a teacher in Batavia. His grandfather taught in Hollandsch-Chineesche School (Dutch-Chinese school in Batavia). With his grandfather, Wieringa's father settled in Batavia until the age of fifteen. After Indonesia declared itself as an independent state, the family then returned to the Netherlands. "In fact, the so-called" return "fits for my grandfather because he was born and raised in the Netherlands. But in

\footnotetext{
${ }^{2}$ Interview with Edwin Wieringa, Cologne, Germany, 24 December 2012.
} 
my father's case, it cannot be called "return" because he was born and raised in Batavia, "Wieringa said in a conversation. "Until my teenage years, I can still remember clearly in our house (in the Netherlands) there was a large map of Batavia at the time when my grandfather was there. The map was posted on the wall. In everyday conversation, my father often used Indonesian words, for example duit, makan, minum, tidur, pagi, siang and malam (money, eating, drinking, sleeping, morning, noon and evening), etc." Wieringa recounted about the nostalgia of family's connection with Indonesia. ${ }^{3}$ Several times I asked him whether his interest was closely related to his grandfather's past in Indonesia. He answered it was very likely but not important. ${ }^{4}$ The most important is that his interest and passion for Indonesia have led him to a more serious academic world. It was not enough just to romance about his family's past.

After two years of studying at the History Department Wieringa moved to the Department of Indonesian Studies. He was disappointed with the materials in the Department of History, which is too Eurocentric. Discussion about Asia also always within the European framework. On this Wieringa recounts:

At the time he was a student in the Department of History, the required history textbook was A History of the Modern World (first printed in 1950) the work of three American historians, Robert Roswell Palmer, Joel Colton, and Lloyd Kramer. However, after seeing the contents of the history of the modern world, the first map was Europe. I began to wonder: what kind of book is this? It seems as if Europe was the most important. The first chapter is about the Rise of Europe and the European Leadership, i.e. Western Europe became the leading forces, and other things about Europe. Then there is discussion about Asia, but under the sub-chapter of Europe World Supremacy, how Europeans colonized and dominated Asia. So, this book is all about Europe, Asia is discussed after Europe dominated Asia, and after the Second World War with the emergence of several independent states, then that is the end of the book with almost 1000 pages. America is discussed but viewed as the successor of the European culture, because Europe is considered a determinant of the modern world. American which became modern in the 19th century is regarded as the successor to European culture, and America is a "new form" of Europe that is more powerful than anything. ${ }^{5}$

With such materials, Wieringa's thirst on Asia from the perspective of the Asians themselves was not met. Everything was always from the perspective of the West (Europe). After moving to the Department of Indonesian Studies,

\footnotetext{
${ }^{3}$ Interview with Wieringa, Cologne, Germany, 24 December 2012.

${ }^{4}$ Interview with Wieringa, Leiden-Belanda, 12 November 2012.

${ }^{5}$ Interview with Wieringa, Cologne, Germany, 24 December 2012.
} 
Wieringa then attended an Indonesian language lecture by Professor Blust. This lecture was interesting and increased his interest in the Indonesian culture. This department in fact offered two concentrations, i.e. Asia (Indonesia) concerning its modern socio-politics and economy, and the second was the traditional culture. Wieringa chose the second concentration, especially Javanese and Malay manuscript. In fact, at the time, the study of ancient manuscripts was among the most favorite at Leiden. Finally, Wieringa dicided to choose Indonesian Studies without considering his future career prospects. The important thing was merely to satisfy his passion and interest. ${ }^{6}$

According to Wieringa, it is important to note that in Leiden in the 1980s, the influence of 19th century Dutch scholarly traditions was still very strong. For example, many people assume that Java was the same as Indonesia. In addition, the use of texts as historical sources was still unusual. Manuscripts were read and studied as literature. It was actually quite disappointing for Wieringa because he wanted to use the ancient texts as historical sources. According to Wieringa, historians and manuscript experts usually did not care about each other, even though they studied the scripts that are closely related. However, these conditions posed a challenge to Wieringa. After successful completion of the Indonesian studies for four years, Wieringa received an offer to be a researcher in Southeast Asia and Oceania and needless to say got a salary. This research program was a project that had existed since the colonial period. At first, the program --which was equivalent to a doctorandus degree (Drs.)-- was held for the colonial civil servants. However, after Indonesia's independence until the 1970s, there were no students taking the program anymore. After 1970, there were several students interested in Indonesia and the concentration of the same study, the ancient Javanese culture. When Wieringa accepted the offer for this program in 1984, the subjects preferred were still on the Javanese history and literature such as kakawin, babad, poetry, and saga. Almost nothing about modern Indonesia. However, in the following years, there was a very fundamental change in the program. This time, Indonesia was discussed in more common materials with its modern aspects. The lectures on traditional culture, including the subject of ancient manuscripts were no longer delivered. With this change, the Old Javanese literary tradition became disconnected, and Wieringa could be referred to as the last generation of the program within the University of Leiden. ${ }^{7}$

In 1988 Wieringa attended a postgraduate program in a project called AIO (Assistent in Opleiding), a program which allowed fresh undersgraduates

${ }^{6}$ Interview with Wieringa, Cologne, Germany, 24 December 2012.

${ }^{7}$ Interview with Wieringa, Cologne, Germany, 24 December 2012. Conversation with Wieringa in Leiden-Belanda, 12 November 2012. 
(Drs.) to directly write the dissertation. Through this program, postgraduate students, including Wieringa, was prepared to become a teaching assistant, but the main obligation was to write a dissertation. Wieringa then took Javanese Script Studies as his concentration, with a draft of the dissertation on Sunan Pakubuwono VI.

For his dissertation research, in 1991 for the first time, Wieringa arrived in Indonesia. With official permission from LIPI, he began his adventures in the libraries in Jakarta, Central Java, and Ambon to look for references and texts related to his research. In Central Java, he traveled around Surakarta (Solo) and Yogyakarta. In these places, he found many versions of the manuscript on Pakubuwono VI. In Yogyakarta he got a "special assistance" from an expert on Javanese Script, Professor Darusuprapta who gave him flexibility for research. Over a year Wieringa stayed in Yogyakarta and Solo. During this time in Yogyakarta, he met Hesti Widyawati, a sweet girl from Solo. Wieringa fell in love and began to approach her. ${ }^{8}$ According to Hesty, Wieringa revealed to him that she was his first love. ${ }^{9}$ Apparently for Wieringa, Java is not only beautiful and exotic in terms of culture. Javanese girls are equally beautiful and alluring as manuscripts are. They got married in 1991 at the home of Hesti's parents in Solo, and now have two daughters with a Dutch-Javanese mix. To date, his family settles in Hurth, a small small town in the neighboring big city of Cologne, Western Germany.

Wieringa wrote his dissertation about the history of the life of Sunan Pakubuwana (PB) VI, better known as Sunan Bangun Tapa since he was exiled (a.k.a Mbangun tapa) in Ambon. In the literature of Surakarta, the exile of PB VI attracted the attention of many people that there are dozens of Javanese scripts that describe the history of the King. PB VI's exile occurred after Diponegoro War in 1830 and it was linked to political reasons, i.e. PB rebellion against the Dutch. As a consequence, PB VI was then made a national hero in Indonesia because he was regarded as a resistance fighter. However, by reading ancient Javanese manuscripts about PB VI, soon we know the real facts that PB VI had personal problems with his wives, especially with his favorite one, i.e. Ratu Anom. Therefore, on June 6, 1830, he suddenly left the palace without asking permission from the Dutch government; he wanted to "retreat" to Imogiri and Parangtritis. In these two places that are considered sacred, the king expected to receive guidance for solving his household problems. However, the Dutch government had another perception. They arrested PB VI on the grounds that the king was planning a rebellion. ${ }^{10}$

${ }^{8}$ Interview with Wieringa, Cologne, Germany, 24 December 2012.

${ }^{9}$ Conversation with Hesti, Cologne, 27 November 2012.

${ }^{10}$ According to Wieringa, the Dutch were very upset by PB VI who was stubborn 
Javanese manuscripts about PB VI consist of many versions, and Wieringa's Dissertation took the oldest edition with a Dutch translation and related notes. He also made detailed notes of the manuscripts of other versions of PB VI. According to Wieringa, there are a lot of history books that talk about PB VI, but a study of ancient Javanese texts that discuss the history of PB VI hae yet to be conducted, whereas the Javanese sources are much deeper and broader than the Dutch. He did what seems to have never been done by other scholars, including Indonesians. Strangely, however, to date the Dutch references still take precedence over Indonesia's own resources. For Wieringa, everything about Indonesia would be more attractive if one can access and understand directly from the sources of Indonesia and the Indonesian people's views rather than the views of non-Indonesians. ${ }^{11}$

In 1994 Wieringa completed his dissertation cum laude, the highest academic achievement in Leiden and rarely given to post graduate students. Wieringa was then given a job as a catalog maker for Malay and Minangkabau manuscripts at the Library of the University of Leiden. Previously, in 1992, after returning from Indonesia, Wieringa taught Javanese literature for undergraduate and graduate students replacing Professor Ras, his own supervisor who retired in 1992. Later, from 1996 to 1998, together with Prof Platenkamp, he got a chance to do a postdoctoral research with a scholarship from the Alexander von Humboldt, Germany. For two years, Wieringa and his family lived in Münster. For him, being a researcher at the German postdoctoral program was happiness and new hope to a better life and career because in Holland he never had a fixed position both as a academic and a researcher. ${ }^{12}$

It was in 2004 Wieringa got what he wanted, as he was appointed a full professor in the field of Indonesian Philology with a Specialization in Indonesian Islamic Culture at the University of Cologne, in Cologne, Germany. As a prolific writer, since 1990 to date, Wieringa has written five books and tens of articles in English, German, Dutch, and Indonesian.

\section{READING THE HISTORY OF DEMAK MOSQUE WITH A CHRONO- GRAM}

In the history of Indonesian Islam, the Demak Grand Mosque in Demak, Central Java is considered the oldest mosque in Indonesia. The mosque is

and unruly. The Dutch was furious when PB VI went to Imogiri without asking for permission. The departure without permission was considered as rebellion. Interview with Wieringa, Cologne, Germany, February 10, 2013.

${ }^{11}$ Interview with Wieringa, Cologne, Germany, 10 Februari 2013.

${ }^{12}$ Interview with Wieringa, Cologne, Germany, 24 December 2012. 
believed to be a gathering place for Wali Songo (Nine Guardians) who spread Islam in Java. The founder of this mosque was supposedly Raden Patah, the first king of the Demak Sultanate around 15th century AD. Raden Patah together with Wali Songo constructed this mosque by inscribing an image of an animal (turtle). It is a candra sengkala memet, meaning Sarira Sunyi Kiblating Gusti or the year 1401 Saka. The body of a turtle consists of a head which means the number 1 (one), 4 feet means the number 4 (four), the body mean the 0 (zero), the tail means the number 1 (one). From this symbol, it is estimated that the Demak Mosque was constructed in 1401 Saka. This mosque was founded on $1^{\text {st }}$ day of Shofar. ${ }^{13}$

According to Wieringa, what is intesting about the Demak mosque is in addition to being a symbol of the advent of Islam in Java, it also has an fascinating history of its construction: when exactly was the Demak mosque constructed? Western scholars or historians trained in the Western tradition always want to find out the facts. The Demak mosque is believed to be the oldest in Indonesia. Therefore, Western historians will look for facts: when was the mosque constructed? In what year? According to Wieringa, questions regarding the history of the mosque cannot be answered with the West methodology because there are many Javanese sources (ancient manuscripts) containing symbols that are complex and differ from one another. However, the official explanation about the construction of the mosque is that it was constructed in the Saka year of 1401 as mentioned above. For Wieringa, it is interesting to trace the historical records of the Demak mosque by reading the chronograms of Demak, Yogyakarta and Solo, and the chronograms of found in Serat Centini, Babad Tanah Jawi, and Babad Cirebon. ${ }^{14}$

In Kamus Besar Bahasa Indonesia [the Great Dictionary of the Indonesian Language] (2008) dan Kamus Besar Ilmu Pengetahuan [the Great Dictionary of Science] (1997), kronogram is defines as a sentence, a word, or a sign that denotes a year or era. So, kronograms are symbols in the form of words, sentences or sign denoting a year, time or period. ${ }^{15}$ According to Wieringa, the determination of the numbers in the chronogram is in accordance with the views of the ancient Javanese people based on Indian-Hindu mythology, and was further developed by the wise Javanese people. ${ }^{16}$ Furhermore, Wieringa July 2015

13 "Masjid Agung Demak," www//http.id.wikipedia.org, article diakses tanggal 2

${ }^{14}$ Interview with Wieringa, Cologne, Germany, 10 Februari 2013.

${ }^{15}$ Department of National Education, Kamus Besar Bahasa Indonesia (Jakarta: Gramedia Pustaka Utama, 2008), p. 743. See also Save M. Dagun, Kamus Besar Ilmu Pengetahuan (Jakarta: The National Institute of Cultural Studies, 1997), p. 546.

${ }^{16}$ Department of National Education, Kamus Besar Bahasa Indonesia (Jakarta: Gramedia Pustaka Utama, 2008), p. 743. See also Save M. Dagun, Kamus Besar Ilmu Penge- 
argued that Javanese sources also do not mention the fact for sure, but merely through symbols or sengkolo. Such symbols have typical meaning. The mention of the Saka year of 1401 is a symbol that represents the beginning of a new era, the era of Islam. ${ }^{17}$ For the Javanese, Saka yearof 1400 (about 1478-9 AD) is the fall of the kingdom of Majapahit that represented Hindu-Buddhism. A year after that, i.e. in 1401 the Demak Sultanate was founded and led by the Adipati Raden Fatah, a Chinese Muslim, who had a Chinese name Jin Bun. Her mother is a pure Chinese. His Arabic name "Fatah" most likely means "victory," meaning the victory of Islam over the Majapahit and a beginning of a new era of Islam. The history of Raden Fatah mentions that he was the first Demak king who ruled from 1500 to $1518 .{ }^{18}$ According to Wieringa, one of Javanese historical records which he read from a Javanese chronicle written by Prince Suryanagara in Yogyakarta in 1865 mentions that:

The number 1400 was the year of $B a$ (of an eight year cycle), the period of the fall of Majapahit, Brawijaya fled with his wives and children, marking the end of Buddhism. The number 1401 was the year of Wawu, i.e. the period of the Demak palace, Raden Patwa (Fatah) started to rule the kingdom and was styled Sultan Bintara. ${ }^{19}$

Another chronicle, Babading Sangkala, written in 1738 also mentioned the fall of Majapahit in the Saka year of 1400. Therefore once again, the Saka year of 1401 was a new era of the rule of Javanese Islam. This year is believed to be the year Raden Fatah became king, however, there is no definitive data that mentions that it was the year the Demak mosque was constructed.

According to Wieringa, the history of the Demak mosque is surrounded by legends that make it difficult for historians to reconstruct objectively about when exactly it was constructed. One popular legend mentions that it was constructed by the Wali Songo in one night. Sunan Kalijaga, one of the Wali Songo, stated that he had played a very important role in the the final construction of the mosque, especially diciding on the direction of qiblat in the mosque. Another interesting legend is the story of Ki Gedhe Sesela or Ki Ageng Sela ${ }^{20}$ who was said to catch lightning while on the farm. The lightning

tahuan (Jakarta: The National Institute of Cultural Studies, 1997), p. 546.

${ }^{17}$ Edwin Wieringa, "A Monument Marking The Dawn Of The Muslim Era In Java: Chronicles and Chronograms on The Grand Mosque of Demak," in Dietrich Boschung and Corinna Wessels-Mevissen, ed., Figurations Of Time In Asia (München, Germany: Wilhelm Fink Verlag, 2012), p. 62.

18 "Raden Fatah," http//www.id.wikipedia.org, article accessed on 2 July 2015.

${ }^{19}$ Wieringa, "A Monument Marking The Dawn Of The Muslim Era In Java," p. 162.

${ }^{20}$ Kyai Ageng Sela or Ki Ageng Ngabdurahman was a spiritual leader and the ancestral king of the Sultanate of Mataram. He was a teacher of Sultan Adiwijaya Pajang founder of the Sultanate, and was the grandfather of the founder of the Sultanate of Mataram of Panembahan Senapati. The story of his life in general was a legend, according to the Chronicle manuscripts. "Ki Ageng Sela," http//www.id.wikipedia.org, article accessed on 2 July 2015. 
later turned into an old man who was presented as a prisoner to the Sultan of Demak. However, the old man later escaped from prison. ${ }^{21}$ To commemorate the miracle of Ki Ageng Selo, the entrance of the Grand Mosque of Demak was called Kori Bledheg or Lawang Bledheg (door of lightning), carved with ornamental plants having an animal head as a symbol of lightning caught by Ki Ageng. In fact, some Javanese people until today will immediately say that they are the grandchildren of Ki Ageng Sela when there is a lightning, hoping it will not strike them. ${ }^{22}$

According to Wieringa, four Javanese chronograms provide different information regarding the construction of the Demak mosque. The first or the oldest chronogram also known also sengkala Memet ${ }^{23}$ describes the Door of Lightning (Lawang Bledheg). The carving on the door indicates the chronogram of naga sarira wani, which is interpreted as the year of Saka 1388 or $1466 \mathrm{AD}$. The second chronogram is the chronogram of turtle found in the sanctuary, which reads sarira sunyi kiblating Gusti. Sarira. Sarira or body equals to the number 1, sepi (silent) is 0, the qiblat is the number 4 and Gusti is the number 1, which is interpreted as the Saka year of 1401 or 1479 AD. The third chronogram is the chronogram of Demak which mentions lawang trus gunaning janmi. Lawang or the door equals to the number 9, trus equals to the number 9, guna or usefulness equals to the number 3 and janmi or human equals to the number 1, which is interpreted as the year Saka of 1399 or $1477 \mathrm{AD}$. The fourth chronogram is the chronogram Lightning Door itself (Kori Bledheg). On the door there is a sentence that reads kori roro gawening wong. Kori which means the door equals to the number 9, roro is the number 2 , gawening or conducted equals to the numbers 4 and wong is the number 1 , so it is interpreted that the Demak mosque was constructed in the Saka year of $1429 .{ }^{24}$

In addition to the four chronograms above, there are other chronograms in the different chronicles with different information. For example, at the entrance of the Demak mosque it is now officially written that the mosque was constructed by the Walis with certain time, i.e. $1^{\text {st }}$ Dzulhijjah in the Saka year of 1428 or $1506 \mathrm{AD} .1^{\text {st }}$ Dzulhijjah means the first day of the month of pilgrimage and the last month of the Islamic calendar. This information seems to be based on the Babad Tanah Jawi (Tanah Jawi chronicle) containing one chronogram mentioning kari roro karyeng janma: kari (left) equals to the

\footnotetext{
${ }^{21}$ Wieringa, "A Monument Marking The Dawn Of The Muslim Era In Java," p. 168.

22 "Ki Ageng Sela," http//www.id.wikipedia.org, article accessed on 2 July 2015.

${ }^{23}$ Sengkolo memet means the expression of years of an event but does not use words, only through symbols.

${ }^{24}$ Wieringa, “A Monument Marking The Dawn Of The Muslim Era In Java," p. 170.
} 
number 8 , roro equals to number 2 , karyeng or work together equals to the number 4 and janma or humans equals to the number 1 , so it is interpreted to be the saka year of $1428 .{ }^{25}$ According to Wieringa, there is another version of the Yogyakarta chronogram written in 1777. In the chronogram, it was mentioned that the construction of the Demak mosque was not at the end of the Islamic calendar, in the month of Dzulhijjah; it was constructed in Suro or Muharram in the Islamic calendar. Chronogram it mentions paksi kerdha neng Samodra: paksi or equal to the number 1 bird, bird kerdha is 1, neng or is number 1, and Samodra or the ocean together with the number 4 , so it is interpreted to be the year Saka1114. ${ }^{26}$

According to Wieringa, in addition to the two chronograms above, there are other two chronograms, i.e. the chronogram in Serat Centini and the chronogram in the babad Cirebon. Serat Centini was one of the greatest literary works in New Javanese literature. Serat Centini is also a collection of all kinds of knowledge and Javanese culture, so as not to become extinct and remain stable over time. It is delivered in the form of songs and the writing is grouped by type of songs. Overall the songs amounted to 725. Centini was written in 1814 AD in Surakarta on the will of Kanjeng Gusti Pangeran Adipati Anom in Surakarta, a son Kanjeng Susuhunan Pakubuwana IV. Later Adipati Anom was crowned Sunan Pakubuwana V. ${ }^{27}$

Centini recounts the adventaures of the three children of Sunan Giri, i.e. Jayengresmi, Jayengsari, and Rancangkapti after being defeated by Prince Pekik of Surabaya, brother in law of Sultan Agung of Mataram Kingdom. The three of them left after the power of Giri was destroyed by Mataram..$^{28}$ It was narrated that Jayengresmi headed west, while Jayengsari and Rancangkapti headed southeast. One of the areas visited by Jayngresmi was Demak and the Demak mosque. Centini mentions that the Demak mosque was constructed by the Walis. Centini then wrote the chronogram of the construction of the mosque by mentioning: Kori roro gawening wong engelneki, which means kori (door) is the number 9, roro the number 2, gawening the number 4, and wong is 1, so according Centini, the Demak mosque was constructed in Saka 1429. However, Centini never mentioned the picture of turtle or chronogram about turtle. ${ }^{29}$

Additional information that appears in the chronicle of Cirebon tells an

${ }^{25}$ Wieringa, “A Monument Marking The Dawn Of The Muslim Era In Java," p. 173.

${ }^{26}$ Wieringa, "A Monument Marking The Dawn Of The Muslim Era In Java," p. 173-

74 .

27 "Serat Centini," http//www.id. wikipedia.org, article accessed on 2 July 2015.

28 "Serat Centini," http//www.id. wikipedia.org, article accessed on 2 July 2015.

${ }^{29}$ Wieringa, "A Monument Marking The Dawn Of The Muslim Era In Java," p. 176-

77. Interview with Wieringa, Cologne, Germany, 10 February 2013. 
interesting expression of Sunan Kalijaga. In the chronicle of the Sunan said:

Jebleng gegatheleng ngasu punika

Iki sangkalaning masjid

iya masjid Demak

Sunan Kali kang nganggita

para Wali anduluri

ing kersanira

kersane Sunan Kali ${ }^{30}$

According to Wieringa, an expression of the Sunan: Jebleng gegatheleng ngasu contains an interesting chronogram because it was mentioned by Sunan Kalijaga, one of the leading Walis believed to have completed the construction of the Demak mosque. The full chronogram version of the jebleng sentence is mungal-mangil mungup jebleng gegatheleng ngasu: Mungal-mangil equals to the number 1 , mungup equals to the number 1 , jebleng equals to the number 4 , and gegatheleng ngasu equals to the number 1. Thus, according to Wieringa, through this chronogram Sunan Kalijaga Demak asserts that the construction of the mosque was completed in the Saka year of 1411/1489 AD, and its development had been approved by the Walis. And again, in this chronicle, it does not mention the image of the turtle. ${ }^{31}$

According to Wieringa, all chronograms above show that the construction of the Demak mosque took place in the 15 th century or 16th with dates, months, and years that vary. This fact is quite interesting for researchers to study. There are no uniform, singular, definite and convincing data or facts. Even more interesting for Wieringa is an image of a turtle on the mihrab of the mosque. The ancient Javanese texts did not mention anything about the picture of the turtle. Centini which tells the story of Prince Jayengresmi's pilgrimage and fell in love with the Demak mosque, according to Wieringa, did not mention the turtle. ${ }^{32}$ In another note, Raden Mas Rahmat (a.k.a Raden Sumasari or Mas Juragan Sumareja), a Javanese aristocrat that became a Demang in Demak in

${ }^{30}$ Wieringa, "A Monument Marking The Dawn Of The Muslim Era In Java," p. 181.

${ }^{31}$ Wieringa, "A Monument Marking The Dawn Of The Muslim Era In Java," p. 181.

${ }^{32}$ Interview with Wieringa, Cologne, Germany, 10 February 2013. Regarding Jayengresmi who fell in love with the Demak mosque, it was told by Centini as follows: Kredyating tyas kapencut arsa udani///ing masigit Demak//iyasaning para wali//tan cinatur laminira. According to Wieringa, Jayengresmi telah kredyating tyas means "wonder in the heart", dankapencut means "interested, fall in love or be tempted" to the mosque of Demak (ing masigit Demak). See Wieringa, "A Monument Marking The Dawn Of The Muslim Era In Java," p. 177-78. 
the 19th century and claimed to have descended from the teachers Demak kept a diary in the 1880s about his pilgrimage to ancient Hindu temples of and some boarding schools in Java. Mas Rahmat also stayed in the Demak mosque to get blessings of the Walis. In the diary, when describing the Demak mosque, he did not mention the image of turtle. ${ }^{33}$ Thus according to Wieringa, the picture of the turtle was not significant or even did not exist in the 19th century though it has now become an important ornament and symbol in the Demak mosque. Many questions arise that require further research: is it true as believed-- that the turtle had been there since the mosque was constructed? Did the writers in the 19th century who made a pilgrimage to the Demak mosque consider drawing of a turtle did not really matter that it escaped their attention? Or did the picture of the turtle emerge recently when the mosque was renovated in the 20th century? Everything is still shrouded in mystery. ${ }^{34}$

With different information about the year of the construction of the mosque and puzzle of the turtle, Wieringa stated that he was actually still felt curious or had a lot of questions about the mysteries of the Demak mosque with all attributes. According to him, by questioning a lot of things, he would like to invite readers in Indonesia to be critical. However, Wieringa insisted that he did not say that the stories of Demak mosque were merely a myth, a lie, or a fairy tale that do not correspond to the facts. There are two important things Wieringa wanted to say. First, there are many sources that should be read with a variety of perspectives. Each chronicle and chronogram has a different interpretation, because the scientific capacity and experience of the authors were different from each other. However, this fact also illustrates the wealth of Javanese sources that show the culture, civilization, intelligence and mindset of the Javanese people in the past were very high and complex. Only a civilized society that is capable of writing a story or event by using complicated symbols. Second, it also shows the concept of time for the Javanese community in particular and Southeast Asia in general. The concept of time for them is very different from those of Europe, for example. For the Javanese, the meaning of time is "special," not just a series of numbers, dates, and events, but it always symbolizes something, especially something sacred. Therefore, the Book of Primbon for instance, which contains good or bad time to do something, is considered important to the Javanese. Again, the Saka year of 1400 is believed to be the fall of the Hindu and Buddhist Majapahit, and one year after, it was the Islamic New Year in Java, though not necessarily understood that in 1400 the lives of Hindus and Buddhists were over as they all converted to Islam. ${ }^{35}$

\footnotetext{
${ }^{33}$ Wieringa, "A Monument Marking The Dawn Of The Muslim Era In Java," p. 175.

${ }^{34}$ Interview with Wieringa, Cologne, Germany, 10 February 2013.

${ }^{35}$ Interview with Wieringa, Cologne, Germany, 10 February 2013.
} 


\section{READING OTHER SIDE OF THE MECCA AND MEDINA POETRY}

From the minds of the Javanese people regarding the Demak mosque, now we move on to another work of Wieringa on the minds of the Minangkabau Muslims in understanding of what is right and wrong in religion in the Syair Mekah dan Madinah (abbreviated SMM). In 2002 Wieringa wrote an interesting article titled A Tale of Two Cities and Two Modes of Reading: A Transformation of the Intended Function of the Syair Mekah dan Madinah which portrayed two perspectives in reading the Syair Mekah dan Madinah. This poetry was written by Sheik Daud, a religious teacher of Shafi'i mazhab to avenge his defeat in a debate with Tuanku Lubuk Ipuh, a Syattariyah scholar who adopted the Martabat Tujuh (Dignity Seven). ${ }^{36}$ At this time in Minangkabau, Syattariyah congregation was called the Ulakan or orthodox religion. It was narrated that at the beginning of the 19th century, Sheik Daud who had just finished studying theology at Darek (interior of Minangkabau) and to some extent had been affected by the view of the puritanical Padri, returned home to Sunur in Pariaman (the coastal area) where the orthodox (Syattariyah tariqa) were strongly entrenched. ${ }^{37}$

In the village, Sheik Daud spread a reformist form religious view and often criticized the tariqa. Tuanku Lubuk Ipuh, a prominent Syattariyah figure invited Sheik Daud to debate theological issues in public. In the debate, Sheik Daud lost. Embarrassed, he then "escaped" to Mecca for pilgrimage and sought knowledge. ${ }^{38}$ According to Wieringa-quoting Sheik Daud Arnold Snackey-Sheik write SMM in Mecca in 1838 concurrent with the pilgrimage which he did in that year. ${ }^{39}$ In a poem written in Mecca, Sheik Daud showed his opposition to the followers of the Ulakan Religion. In the study of Sufism (the science of truth), for example, Sheik Daud warned the Javanese pilgrims to be careful in choosing a teacher, so as not to "go astray" as the adherents of Syattariyah. Sheik Daud wrote, as quoted by Suryadi:

${ }^{36}$ Edwin Wieringa, "A Tale of Two Cities and Two Modes of Reading: A Transformation of the Intended Function of the Syair Mekah dan Madinah “Die Welt des Islams (2002), p. 186.

${ }^{37}$ Suryadi, "Kitab Manasik Haji Pertama In Bahasa Melayu," in A.B Lapian et al., ed., Sejarah dan Dialog Peradaban: Persembahan 70 Tahun Prof. Dr. Taufik Abdullah (Jakarta: LIPI, 2005), p. 276.

${ }^{38}$ Wieringa, "A Tale of Two Cities," p. 186. Suryadi, "Kitab Manasik Haji," p. 276.

${ }^{39}$ Wieringa, "A Tale of Two Cities," p. 186. 
Tuan belajar Ilmu Hakikat,

Betul di innya jalan makrifat,

Carilah gurumu janganlah sesat,

Satukan syariat dengan hakikat.

Ilmu yang salah banyak sekarang,

sebab muftinya tiadalah terang,

setengah iktikad tiada sembahyang,

puasa dan zakat ia dilarang

[You learnt the Science of Truth,

True in it the way of gnosis,

Look for your teachers, do not go astray,

Combine the Sharia with truth.

Mad science is widespread now,

For the mufti are not bright,

half-faith and no prayer,

fasting and alms were banned. $]^{40}$

According to Suryadi, what Sheik Daud meant by the mufti prohibiting fasting and alms were none other than the scholars of the Orthodox. Sheik Daud this time lived in Mecca to fight and attack the Syattariyah through his poems though he no longer came face to face with the Sheik Lubuk Ipuh. ${ }^{41} \mathrm{He}$ also criticized the attitude of the Orthodox who claimed to be Muslim but did not perform the Friday prayer in congregation:

Sungguhpun satu baginya firak,

Bukan ittihad pada segenap pihak,

WahidNya dan kaim (kebakaan) Jumatan tidak,

Mustahillah pulak in khalayak

[Even though one for them is firak,

Not ittihad for everyone,

His oneness and Kaim (immortality) not performing Friday prayer,

Impossible to be in the audience. ${ }^{42}$

\footnotetext{
${ }^{40}$ Suryadi, “Kitab Manasik Haji”, p. 297.

${ }^{41}$ Suryadi, “Kitab Manasik Haji,” p. 297.

${ }^{42}$ Suryadi, “Kitab Manasik Haji,” p. 298.
} 
According to Suryadi, in the years when Sheik Daud was living in Mecca, Wahhabi movement pioneered by Muhammad bin Abdul Wahhab, was rampant. The movement that focused on purification of puritanical monotheism and resisted Sufism, especially wahdatul wujud and Martabat Tujuh. According to Suryadi, in Sumatra, religious reform movement was already known in the late 19th century brought by three hajj of Minangkabau: Haji Miskin, Haji Sumanik, and Haji Piobang. Now in Mecca, Sheik Daud went through and witnessed the Wahhabi wind of change that was blowing hard. ${ }^{43}$ In SMM, Sheik Daud also reported that the doctrines of Martabat Tujuh had been banned in Mecca by the Wahhabi:

Martabat Tujuh masa sekarang,

Di negeri Mekah sudah dilarang,

berapa kitab sudah dibuang,

ahlinya tiada muftinya jarang.

Mufakat ulama di Mekah Madinah, demikian lagi Mesir dan Kufah, martabat Tujuh sekarang tertegah, menuntut dia akhirnya salah

[Martabat Tujuh now,

In the land of Mecca has been banned, Several books have been discarded, No scholars, its muftis are rare.

Consensus of scholars in Mecca Medina, So are Egypt and Kufa, Martabat Tujuh now is losing ground, It claims but finally lost. ${ }^{44}$

Even though he rejected Sufism wahdatul wujud and martabat tujuh, Sheik Daud was fond of Al-Ghazali Sufism. Therefore, in the SMM he often praised Imam al-Ghazali and his books like Ihya Ulum al-Din, Bidayat al-Hidayah, and Minhaj al-Abidin. In the poems, he also recommended Muslim students to study the works of al-Ghazali.

\footnotetext{
${ }^{43}$ Suryadi, "Kitab Manasik Haji”, p. 298.

${ }^{44}$ Wieringa, “A Tale of Two Cities," p. 195. See also Suryadi, "Kitab Manasik Haji," p. 298.
} 
In general, in addition to the fight against Syattariyah in Minangkabau, SMM also contained long account of beautiful and distinctive cities of Mecca and Medina, the atmosphere of intellectual and academic traditions in Mecca, many famous scholars of Mecca, the virtue of studying Islamic sciences such as sciences of mantiq, ma'ani, tools, tafsir, hadith, tawhid, mysticism (Sufism), etc. Related to the fact that many poems in SMM were about the importance of pilgrimage and the primacy of Mecca and Medina, the SMM is often referred to as Syair Rukun Haji (SRH) [Poetry of the Pillar of Hajj]. ${ }^{45}$

According to Wieringa, the unique features of SMM or SRH are the fact that the poems turned out to have three interesting sides. First, SMM written by Sheik Daud was actually intended for a small group of Minangkabau people, especially to show resistance to the Syattariyah in his hometown of Sunur village in Pariaman. Therefore, according to Wieringa, a book of poetry was indeed localized only to a limited audience, i.e. the context of the Minangkabau, or readers who understood Malay. ${ }^{46}$ Why Sheik Daud wrote it in Mecca? According to Wieringa, it is because Mecca had a very special place for Indonesian Muslims of the 18th and the 19th century, and by writing poetry in Mecca, Sheik Daud showed that he now had a higher authority than when he was living in Minangkabau - in terms of knowledge of Islam. By using "Mecca" Sheik Daud also wanted to show that he was in a superior position and enemies in Minangkabau in inferior position. As mentioned earlier that Mecca for a long time even until the end of the 20th century was regarded as the "intellectual and spiritual center of Muslims". Mecca was considered a very "sacred, holy, and pure" place for them not only because of the Kaaba, Masjid al-Haram and the birth of Prophet Muhammad, but also because there is a "center of Islamic scholarship" that directs the activities of worship and Islamic scholarship throughout the Islamic world at that time. What was decided or issued in the form of fatwa by scholars of Mecca will be followed by Muslims, including Indonesian Muslims. By writing in Mecca and distributed to Minangkabau, Sheik Daud hoped that he would be considered to have "special position" among Muslims of Minangkabau. ${ }^{47}$

Second, at the end of the 19th century, a publisher in Singapore was looking for a script to be used as a guide book for the Indonesian Haj pilgrims. The publisher then found SMM, so these poems were published for the pilgrims of Indoensia and Southeast Asia that transited in Singapore. It turned out that this book was a best-seller or enjoyed great success commercially. As is the case of commercial magazines today, the book was later published with

${ }^{45}$ The description of this can be found in Suryadi, "Kitab Manasik Haji," p. 290-297.

${ }^{46}$ Wieringa, "A Tale of Two Cities," p. 202.

${ }^{47}$ Wieringa, "A Tale of Two Cities," p. 192-193. 
commercial advertisements in it. It was something new at the time to turn a manuscript into a commercial book. ${ }^{48}$

When printed by publishers in Singapore, the text appeared with a new commercial face with an interesting book cover. For example, in the middle of the cover it is written: "These are the poems of Mecca and Medina whose stories are too beautiful." ${ }^{49}$ On the top side of the cover of the book it is also written: "These are the poems of the new kind of fairy telling people going haj from the land under the wind to the land over the wind like Jedda and Mecca and Medina and so forth." Then, on the bottom of the cover of the book it is also written: "Whoever wants to know the beauty of Mecca, Medina and the tomb of the Prophet salla 'llahu' alayhi wasallam, and the behaviors of people who go to perform haj please check out these poems." All of this additional information on the cover certainly did not come from Sheik Daud but an advertisement from the publisher to attract Hajj pilgrims to make a purchase. $^{50}$

According to Wieringa, on the cover of the book there are words that are emphasized such as "too beautiful a story" and "elegance of Makah - Medina" Again for Wieringa, the words "beautiful" and "elegance" were emphasized by publishers to impress prospective readers that the book was indeed "unusual and awesome" and was full of beautiful poems that would make readers fall in love, and the most important was to make them amazed at Mecca and Medina. All the advesrtisement campaign was none other than a trick to sell a bestselling book. ${ }^{51}$ Eventually, SMM which was then called SRH were originally written to challenge the Martabat Tujuh in Minangkabau has now turned into a pilgrimage commercial handbook. According to Wieringa, the process of commercialization of a book is common and natural, not a bad or evil thing. Things that are spiritual in some cases can also be also associated with economic or political motive. Sacred and profane relationships are common, and not something that should be viewed negatively. ${ }^{52}$ Again, in terms of the purpose of writing, after being printed with an attractive cover, then the text of SMM which was originally intended for those in his hometown in Minangkabau, has now been printed with a new face and with a new purpose, i.e. as a guidebook for pilgrimage. According to Wieringa, when viewed from

\footnotetext{
${ }^{48}$ Interview with Wieringa, Cologne, Germany, 7 March 2013. See also Wieringa, "A Tale of Two Cities," p. 198.

${ }^{49}$ Wieringa, "A Tale of Two Cities," p. 200.

${ }^{50}$ Wieringa, "A Tale of Two Cities," p. 201. Interview with Wieringa, Cologne, Germany, 7 March 2013.

${ }^{51}$ Wieringa, "A Tale of Two Cities," p. 200-202.Interview with Wieringa, Cologne, Germany, 7 March 2013.

${ }^{52}$ Interview with Wieringa, Cologne, Germany, 7 March 2013.
} 
one side, for example, from the scientific side, the reduction of SMM text into a Haj handbook has made the manuscript no longer of interest to researchers. However, when viewed from the other side of the "fresh" printing of the text makes the script popular and in many ways beneficial knowledge for pilgrims who do not have any knowledge of the details of the land of Mecca and Medina. ${ }^{53}$

Third, with the publication of SMM as a new event, then the printing was considered modern and new, although the idea that was printed was something old. Wieringa agrees to the view that a new technique or technology brings renewal, new ideas and change. But according to Wieringa, one must understand that in order to "start something new, it needs something old." In the first stage, printing as a new technology or idea, actually printed the old writings. The idea was actually an old idea but printed with a new technology. There is always a gradual process from an old tradition to a new model. There is no new thing --a revolutionary way-- directly breaks the old traditions. In the second stage and the following period, the printing or publisher published new ideas, though often the publishers still published an old idea with a new look. ${ }^{54}$ According to Wieringa, scientific studies or research on SMM text has not been done by any scholar. He was the first scholars to examine the SMM. During his study of the poems, Wieringa was quite surprised to find a lot of interesting things. ${ }^{55}$

After Wieringa published his article on SMM in 2002 in Leiden, three years later Suryadi wrote about SMM in Indonesian entitled Kitab Manasik Haji Pertama In Bahasa Melayu (the First Hajj Guide Book In the Malay Language (2005). Suryadi's article was written as a tribute to $70^{\text {th }}$ birthday of Professor Taufik Abdullah. Suryadi is Indonesian scholar who became a lecturer and researcher at the University of Leiden, and according to Wieringa, he and Suryadi used to teach together for undergraduate and graduate students at the University of Leiden. After reading Suryadi's article, Wieringa revealed that he, in some ways, appreciated the work, but there were other things he did not agree with Suryadi. ${ }^{56}$ On page 281, for example, Suryadi wrote:

Wieringa's conclusion: publishers in Singapore intentionally comercializing SRH by printing it repeatedly, advertising it, and market it in order to make profit and take advantage of the strategic location of Singapore as a port of

\footnotetext{
${ }^{53}$ Interview with Wieringa, Cologne, Germany, 7 March 2013.

${ }^{54}$ Interview with Wieringa, Cologne, Germany, 7 March 2013. See also Wieringa, "A Tale of Two Cities," p. 202-204.

${ }^{55}$ Interview with Wieringa, Cologne, Germany, 7 March 2013.

${ }^{56}$ Interview with Wieringa, Cologne, Germany, 7 March 2013.
} 
embarkation of the Indonesian Hajj at the time. ${ }^{57}$

According to Wieringa, it is not true if he concludes the printing of SMM was "solely to make a profit." He only wrote that the book is now highly commercial in which the publication is presented..$^{58}$ According to Wieringa, he only described the "old face" and the "new face" or the "old orientation" and the "new orientation" in SMM to be a commercial book. Again to Wieringa, commercialization aspects of religion are common and normal, it can happen anywhere, and not something negative. However, to Wieringa, Suryadi's article had "judged" him as a Western scholar with a negative view on the commercialization process of SMM text. Wieringa was not "comfortable" with the expression Suryadi used to refer to him as a "foreigner" who accused publishers in Singapore of merely looking for profit. ${ }^{59}$

Another thing --according to Wieringa-- about Suryadi;s article which is improper when commenting on Wieringa's work, Suryadi had a conclusion that at first there were traditions (writing) of the text and then a printing technology emerged. The former was traditional while the latter modern. According to Wieringa, no drastic or radical change from traditional to modern. The change was gradual and slow. To Wieringa, printing technology is not synonymous with modernity or all considered modern because people often publish old ideas or traditions using print technology. The existence of new features does not necessarily break the continuity of the old. It is simply a process of gradual changes that occur in many aspects of life. According to Wieringa, Suryadi had simplified the complex work of Wieringa and therefore Suryadi had a false conclusion. Personally, according to Wieringa, he was quite uncomfortable being labeled by Suryadi as "foreigner" or "Westerner" who did not understand anything about the Indonesian noble traditions. Wieringa regarded Suryadi as a "friend" and hs friend considered him a "foreigner." 60

One of the reviews often cited by Wieringa is a privileged position of Mecca for Indonesian Muslims. In Syair Mekah dan Madinah Wieringa also had a review on the subject. In factdeed, as Azyumardi Azra noted, that since the 17th century Mecca and Medina or also known as Haramayn al-Syarifayn (Two Holy Lands) have got a special position for Indonesian Muslims who performed pilgrimage in quite a large number in the century. According Azyumardi, there are two principal reasons why the Haramayn have got a very special position and very high for the Indonesian Muslims since the 17th

${ }^{57}$ Suryadi, “Kitab Manasik Haji," p. 281-282.

${ }^{58}$ Wieringa,"A Tale of Two Cities," p. 200. Interview with Wieringa, Cologne, Germany, 7 March 2013.

${ }^{59}$ Interview with Wieringa, Cologne, Germany, 7 March 2013.

${ }^{60}$ Interview with Wieringa, Cologne, Germany, 7 March 2013. 
century. First, the combination of the eminence of Mecca and Medina and the teachings of the Qur'an and the hadith of the Prophet to study, eventually give a special position on the appreciation of science or knowledge acquired in Haramayn. Knowledge obtained in Haramayn is deemed of greater value than that obtained in other scientific centers. For many Muslims, especially Indonesian, scholars studying in Haramayn are considered more respected than those who receive education in other places. Second, the pilgrimage season is the largest gathering of Muslims from around the world in both the holy cities. Haramayn serve as the intellectual center of the Muslim world: scholars, mystics, philosophers, poets, businessmen and Muslim historians meet and exchange information there. This is one of the reasons, Azyumardi argued, why the ulemas and students who teach and learn in Mecca and Medina have a more cosmopolitan religious view than those in other Muslim cities. $^{61}$

In an interesting article entitled Mecca Has Spoken, Case Closed: Muhammad Hasan B. Kasim's 1913 Meccan Poem Of Advice On Sarekat Islam (2008), Wieringa once again revealed the special position of Mecca for the Indonesian Muslims in the first decade of the $20^{\text {th }}$ century the article reviewed the emergence of Sarekat Indonesia (SI) in Java in the 1910s and letters sent from Javanese Muslims to Mecca asked for a fatwa about how Muslims should respond to the emergence of the SI. Muhammad Hasan bin Kasim, a Muslim originally from Lengkong, Tangerang (Banten) who lived in Mecca from 1913 to 1914 for Haj and studying, claimed to have received many letters from Muslims in Java who asked him if SI was an "Islamic "organization that was worthy of being followed or not? Many religious leaders in Java stated that the SI organization was "un-Islamic", its programs were ignorant and therefore must have been prohibited by Prophet Muhammad. ${ }^{62}$

According to Wieringa, the questioners of Java were actually the people who asked for a fatwa to Hasan ibn Kasim about the status of the SI and permissibility of becoming a member of the organization. Asking for a fatwa to Mecca or to scholars of Mecca since the 17th century and even until the mid-20th century has been very common for Indonesian Muslims if they ecountered quite complicated religious problems. Again, it happened because Mecca is regerded as the spiritual and inetellectual "center" or "axis" of Islam. In the case of Hasan ibn Kasim, because he felt he was just a student in Mecca

${ }^{61}$ Azyumardi Azra, Jaringan Ulama Timur Tengah dan Kepulauan Nusantara Abad XVII \& XVIII: Akar Pembaruan Indonesian Islam (Edisi Revisi) (Jakarta: Prenada Media, 2004), p. 51-52.

${ }^{62}$ Wieringa,'Mecca Has Spoken, Case Closed: Muhammad Hasan B. Kasim's 1913 Meccan Poem Of Advice On Sarekat Islam, ” in K.D Hulster and J. Van Steenbergen, ed., Contuinity and Change In The Realms Of Islam (Leuven: Peeters, 2008), p. 637. 
and not a cleric who has authority, consequently he could not be a mufti and therefore he did not dare to issue a fatwa to the respondents. So what did he do? First, he sought out and gathered information about the SI from Indonesian pilgrims he met in Mecca. Second, the information he received was consulted with teachers who lived in Mecca, who also originated from Banten such as Raden Muhammad Mukhtar Atarid, Hasan Syadzali, Tubagus Muhammad Syadzali, Ahmad Jaha al-Bantani and Ahmad Marzuki Tanara al-Bantani and some scholars of Mecca who were considered authoritative (whose names were not mentioned).

From the information, discussion, and consultation, Hasan ibn Kasim believed that the SI in accordance with the teachings of the Sharia and Islamic struggle. He and the teacher, Raden Muhammad Mukhtar later became members of the SI in Mecca. They were both inducted into the membership by Raden Aom Abdul Malik, a commissioner of the SI Branch of Cianjur, West Java, who was in Mecca ${ }^{63}$ Hasan ibn Kasim then wrote a thin book containing poems about the glory of the SI and advised the Indoneian Muslims to become members. The book title was in Arabic, the Advice al-Arham li al-Dukhul fi Amr Syarikat al-Islam, but it was poetry in Malay. The poems were later known as the Poems of Advice of Syarikat Islam (SHSI) ${ }^{64}$ Among the support to the SI Ibn Qasim wrote in poems:

Telah datang khabar ke negeri Mekkah berhamburan

Syarikat al-Islam punya aturan

Dari negeri Batavia Bogor sekalian

Kuliling negeri Hindia Nederlan

Ulama Mekah dan awam sekalian

Suka cinta hati senang pikiran

Sebab dengar di negeri Jawi bagus aturan

Perkara agama banyak menyebut Pangeran

Allah taala beri hidayat dan pertolongan

Akan sekalian orang Jawi kemenangan ${ }^{65}$

\footnotetext{
${ }^{63}$ Wieringa, “Mecca Has Spoken, Case Closed, p. 637.

${ }^{64}$ Wieringa, "Mecca Has Spoken, Case Closed, p. 636-37.

${ }^{65}$ Wieringa, "Mecca Has Spoken, Case Closed, p. 646.
} 
Ketahui olehmu sekalian ikhwan

Bagusnya Syarikat al-Islam punya aturan

Dia menyuruh sembahyang jumat kumpulan

Sekalian perintah yang wajib kemestian ${ }^{66}$

Itulah aturan yang tersebut sekalian

Kelewat bagus menurut hukum Qur'an

Sekalian ulama Mekkah memuji ini aturan

Dan syukur akan Allah taala punya kurniaan ${ }^{67}$

Mudah-mudahan Allah taala berikan sekalian

Orang Jawi dan orang Tangerang

Akan Syarikat Islam punya aturan

Supaya dapat rahmat ridha pangeran ${ }^{68}$

Sekalian orang negeri Mekkah puji sekali

Aturan Syarikat Islam di Batavia

Mudah-mudahan Allah taala memberi

Aturan syarikat sekalian negeri ${ }^{69}$

[the news in great amount has reached the land of Mecca

Syarikat al-Islam has rules

Of the lands of both Batavia and Bogor

Around the Dutch Indies

The clerics and laymen of Mecca

Happy thoughts and joyful heart

For hearing good rules of the Java land

Cases of religion a lot of mentioning the Prince

Allah Almighty, give hidayat and help

So all the people of Jawi with victory

All brothers, be aware

The good Syarikat al-Islam has rules

Asking people to perform Friday prayer in congregation Including all mandatory orders

That is the all the stated rules

${ }^{66}$ Wieringa, "Mecca Has Spoken, Case Closed, p. 646.

${ }^{67}$ Wieringa, "Mecca Has Spoken, Case Closed, p. 647.

${ }^{68}$ Wieringa, "Mecca Has Spoken, Case Closed, p. 648.

${ }^{69}$ Wieringa, "Mecca Has Spoken, Case Closed, p. 648. 
Too good in accordance with the law of the Qur'an

Scholars of Mecca praised of these rules

And praise God Almighty for the blessings

Hopefully Allah Tảala gave all

The people of Java and Tangerang

With Syarikat Islam's rules

In order that the prince will be pleased

All the people of Mecca gave praises

The rules Syarikat Islam in Batavia

Hopefully, Allah Almighty gave

The rules Syarikat all over the land]

Hasan ibn Kasim's confidence was getting stronger when he learned that Habib Utsman (a.k.a Sayyid Uthman), a very influential scholar of Batavia in the colonial period also praised the SI as a "noble and true" Islamic organization. Hasan ibn Kasim's poems also showed that the membership of the SI included the traditional followers of ahlussunnah wal jamaah:

Apalagi ini aturan sudah mufakat

Sekalian ulama ahlussunnah wal jamaat

Apalagi sudah mufakat dengan Habib Utsman

Bintang Batavia di ini zaman

Mesti kita ikut diah punya aturan

Jangan sekali dari diah bersalahan

Ialah kita punya imam perikutan

Ialah bintang agama yang menerangkan jalan

Ialah sayyidul ulama di negeri Batavia

Yang menerangkan agama di negeri Jawi ${ }^{70}$

Afterall this is already a consensus

All scholars of ahlussunnah wal pilgrims

Particularly a consensus with Habib Osman

Batavia star in this era

We must follow his rules

Never question his rules

He is the imam we must follow

${ }^{70}$ Wieringa, “Mecca Has Spoken, Case Closed, p. 650. 
He is the star of the religion that lights the way

He is the leader of the ulemas in Batavia

That explains religion in Java

According to Wieringa, an interesting case of the SHSI is the fact that Javanese Muslims asked for a fatwa to Mecca, but the scholars in Mecca had to seek information from the Javanese who also visited Mecca. It seems as if Mecca knew everything. However the important point was the privileged position of Mecca, irrespective of religious views that issued as fatwa will have a significant impact on the religious mindset and attitude of Indonesian Muslims. Wieringa argued further that SHSI documents also gave very important information, i.e. the membership, role and support of the students and scholars who were traditionally very enthusiastic in supporting the SI movement. In the official history, the SI always mentioned three groups of active members, i.e. the nationalists, socialists and Muslim modernists. It was almost never revealed about the role of the traditional students and scholars in the SI. The SHSI documents turned out to uncover the important role and support of traditional students to the SI organization in the early days of its emergence. In the early days, the SI was a magnet for Islamic groups to join, including the traditionalists. However, the development the SI suffered internal divisions. ${ }^{71}$

\section{“MEANING OF ADILUHUNG” OF INDONESIAN CULTURE}

As mentioned earlier, because he was attracted to the mindset of Indonesians, Wieringa focused his research on the thoughts and culture of the people of Indonesia. In his imagination, what is called Indonesia is not limited to the "Republic of Indonesia" but more than that, i.e. all those who speak Malay. So for Wieringa, Indonesia is the entity and identity vast enough that exhibit similarities of culture and language, in this case the Malay language. Wieringa's view was typical of Western scholars who see the East or Asia within a framework of cultural similarities and language, instead of the territorial boundaries of a country. However, specifically, Wieringa was more interested in the Javanese culture. "I'm interested in the culture of the Malay and Javanese. If I had to choose, I would more inclined to the Javanese culture,"72 Thus he asserted. It was proved that he has written a lot about Javanese culture.

According to Wieringa, the interesting part of Javanese culture is the myth, legend or fairy tale. The terms such as myth, legend or folklore are new terms borrowed from the West, but usually there have been "negative" or "pejorative"

${ }^{71}$ Interview with Wieringa, Cologne, Germany, 10 April 2013.

${ }^{72}$ Interview with Wieringa, Cologne, Germany, 17 April 2013. 
connotation in those terms. Western people who pursue the world of literature will look at fairy tales, stories or legends in a literary work or fiction, not necessarily factual or not necessarily containing historical truth. According to Wieringa, the works of literature in Javanese culture are not like that. There are considerable differences and obvious and significant correlation between the view of the Werterners and that of the Javanese who observe them. Did the early Javanese consider stories or fairy tales merely a legend or a myth? According to Wieringa, absolutely not! For most Javanese, all the stories were considered myths or legends by the present generation in fact had true sublime meaing, at least in the structure of Javanese culture. ${ }^{73}$

Suwardi Endraswara, a scholar of Javanese religion and culture confirmed that the Javanese religion consists of two main aspects: an insight into the spiritual and religious practices. First, the Javanese are believe in the transcendent or the spiritual. For them, the so-called "transcendent" or "spiritual" means there is power above humans. Power is better understood as the unseen which is hard to touch and it is also sublime as well as subjective. ${ }^{74}$ With regard to the spiritual, it is the concept of heresy and myths. Two terms are very close to the Javanese culture and religion. Klenik and Klenikology or the science of klenik highly influences the life of theJavanese in general. According Endraswara, the word "klenik" is always interpreted negatively by many people. Whereas, in Klenikologi, the word "klenik" does not always have a negative and bad meaning. Klenikologi is the science that explores matters of how Javanese people live a complex life and practice the klenik. According Endraswara, based on the klenik, the Javanese religion becomes more advanced and better known. ${ }^{75}$

Another thing related to the klenik is a myth. To Endraswara, the Javanese religion is always closely intertwined with myths. Religion is a "close friend" of mythology. The Myth of Merapi, Nyi Roro Kidul, Mount Lanang, Sukuh and others are among the Javanese religious phenomena. To the Javanese, the myths and the klenik have "special menaing" to explain the world. Unfortunately, according to Endraswara, things that are considered to be supernatural, sublime and spiritual are often used by certain parties to degrade the nature of Javanese religion and consider it a "belief" in stead of religion. ${ }^{76}$

Second, to the Javanese, religion is an act, practice, lelaku or ngelakoni. The Javanese religious practices such as worshiping or praying for the ancestors

${ }^{73}$ Interview with Wieringa, Cologne, Germany, 17 April 2013.

${ }^{74}$ Suwardi Endraswara, Agama Jawa, Menyusuri Jejak Spiritualitas Jawa (Yogyakarta: Lembu Jawa, 2012), p. 26.

${ }^{75}$ Endraswara, Agama Jawa, p. 23.

${ }^{76}$ Endraswara, Agama Jawa, p. 26. 
show that the religious traditions of the Javanese are very old and reflect the civilization itself, i.e. the Javanese civilization that is very old. ${ }^{77}$ With the views of religion and belief among the Javanese people as described by Endraswara, Wieringa on several occasions expressed his concern about many Indonesians and Javanese today who ignore the valuable meanings of the Javanese culture resulting in the fact that there are no serious efforts to preserve it. For example, it is rare to find Javanese language newspapers today, and newspapers or magazines no use the ancient Javanese language (hono-coroko). Wieringa recalled that in 2012 he became a guest speaker for an international conference organized by the University of Gadjah Mada (UGM) in Yogyakarta. At the conference there was a Javanese historian telling the life story of Sultan Agung. Then he cited a chronicle saying that Sultan Agung, every Friday always performed Friday prayer in Mecca and returned to Java in the afternoon. What was the reaction Indonesian people in attendance? Everyone laughed out, thnking that the story was funny; how could it be possible? Wieringa had a strong impression that many Indonesians who attended the seminar thought that the story is just a fairy tale or a legend. Wieringa was concerned that many Indoensians could not understand "an important message" in the story, i.e. that Sultan Agung was a person who observed religion; he was a pious Muslim king. The story of the Friday prayers in Mecca was a kind of illustration that wanted to emphasize the importance of Islam in the life of Sultan Agung. Thus, the story that has an important message is no laughing matter because laughing is seen as 'degrading' even 'insulting' the noble Javanese culture. ${ }^{78} \mathrm{In}$ addition he was also a king who in the Javanese tradition also held the title of Sayidin Panatagama (religious leader) and was also considered a dzillullah or shadow of God or God's representative on earth?

According to Wieringa, as scholars from outside Indonesia he did not have the capacity to judge right or wrong of a story and nor did he have the ability to make an assessment or judgment. However, he just wanted to emphasize that a scholar or anyone should read the text in accordance with the culture which gave birth to it, and should not view it through other cultures. It is not appropriate for Westerners to judge that story or fairy tales in Javanese culture as an empty fairy tale. Similarly, it is also improper for the Javanese to view the Western culture as very poor with spiritual values. Every culture has "typical and unique" values and meaning which cannot be measured by other cultures which have their own world view. ${ }^{79}$

\footnotetext{
${ }^{77}$ Endraswara, Agama Jawa, p. 30.

${ }^{78}$ Interview with Wieringa, Cologne, Germany, 17 April 2013.

${ }^{79}$ Interview with Wieringa, Cologne, Germany, 17 April 2013.
} 


\section{CLOSING REMARKS}

Edwin Wieringa wrote many aspects of the minds of people in Indoensia in the past and the present as well as the phenomena of Indonesian Muslims. Wieringa, for example, wrote a very interesting article about Islam Manga comics in Indonesia and Malaysia $(2013)^{80}$ which describe the Islamic view of the modern comic writers considered to represent a model of urban Muslim Indonesians (who tend to be ideological). Another interesting article is the commercialization of the ancient manuscripts of the Qur'an in Indonesia. ${ }^{81}$ Wieringa carried out study on a codex that was considered ancient and therefore had a high commercial value in the international market when it turned out to be a regular manuscript written by an ordinary student at a boarding school. To Wieringa, various aspects of the minds of Indonesian Muslims in the past and the present will always be exotic, in the sense that they are "special", "unique" and "interesting", and therefore he is always interested in studying a lot of things about the Indonesian Muslims. The exoticism of Muslim culture in Indonesia also indicates a high civilization that must be appreciated by the Indonesian Muslims themselves. Tens of Wieringa's works which explore the culture of Islam in this country show that he has contributed a lot to the development of research and Indonesian Islamic culture.

\section{REFERENCES}

"Ki Ageng Sela," http//www.id.wikipedia.org, article accessed on 2 July 2015. "Masjid Agung Demak," www//http.id.wikipedia.org, article accessed on 2 July 2015.

"Raden Fatah," http//www.id.wikipedia.org, article accessed on 2 July 2015. "Serat Centini," http//www.id. wikipedia.org, article accessed on 2 July 2015. Azra, Azyumardi, Jaringan Ulama Timur Tengah dan Kepulauan Nusantara Abad XVII \& XVIII: Akar Pembaruan Indonesian Islam (Edisi Revisi). Jakarta: Prenada Media, 2004.

${ }^{80}$ The article is entitled "Islamic Manga in Indonesia and Malaysia" (2013). It has not been published but was presented at the International Conference at the Metropolitan University Prague, Czech Republic (November 2013) and a National Seminar at the Faculty of Ushuluddin, UIN Syarif Hidayatullah Jakarta (April 2014).

${ }^{81}$ The article was entitled "The Idea of an Old Qur'an Manuscript: On The commercialization Of The Indonesian Islamic Heritage." The article was published by the Journal of Heritage Of Nusantara, International Journal of Religious Literature and Heritage Vol. 3 No. 1 June 2014. The journal belongs to Center for Research and Development of Religious Culture and Literature, the Ministry of Religious Affairs, Republic of Indonesia. 
Dagun, Save M., Kamus Besar Ilmu Pengetahuan.Jakarta: The National Institute of Cultural Studies, 1997.

Department of National Education, Kamus Besar Bahasa Indonesia.Jakarta: Gramedia Pustaka Utama, 2008.

Endraswara, Suwardi, Agama Jawa, Menyusuri Jejak Spiritualitas Jawa. Yogyakarta: Lembu Jawa, 2012.

Suryadi, "Kitab Manasik Haji Pertama In Bahasa Melayu," in A.B Lapian et al., ed., Sejarah dan Dialog Peradaban: Persembahan 70 Tahun Prof. Dr. Taufik Abdullah. Jakarta: LIPI, 2005.

Wieringa, Edwin, "A Monument Marking The Dawn Of The Muslim Era In Java: Chronicles and Chronograms on The Grand Mosque of Demak," in Boschung, Dietrich and Wessels-Mevissen, Corinna (eds.), Figurations Of Time In Asia.München, Germany: Wilhelm Fink Verlag, 2012.

Wieringa, Edwin, "A Tale of Two Cities and Two Modes of Reading: A Transformation of the Intended Function of the Syair Mekah dan Madinah “Die Welt des Islams, 2002.

Wieringa, Edwin,"The Idea Of An Old Qur'an Manuscript: On The Commercialization Of The Indonesian Islamic Heritage," in Heritage Of Nusantara, International Journal of Religious Literature and Heritage Vol. 3 No. 1 June 2014.

Wieringa, Edwin, “Mecca Has Spoken, Case Closed: Muhammad Hasan B. Kasim's 1913 Meccan Poem Of Advice On Sarekat Islam," in K.D Hulster and J. Van Steenbergen, ed., Contuinity and Change In The Realms Of Islam.Leuven: Peeters, 2008.

Interview with Edwin Wieringa, Cologne, Germany, 12 November 2012, Interview with Wieringa, Cologne, Germany, 24 December 2012,

Interview with Wieringa, Leiden-Belanda, 12 November 2012, Interview with Wieringa,Cologne, Germany, 10 February 2013. Interview with Wieringa, Cologne, Germany, 7 March 2013. Interview with Wieringa, Cologne, Germany, 10 April 2013. Interview with Wieringa, Cologne, Germany, 17 April 2013. 